\title{
REVIEW
}

\section{T cell plasticity in renal autoimmune disease}

\author{
Shiwa Soukou ${ }^{1,2} \cdot$ Samuel Huber ${ }^{1,2} \cdot$ Christian F. Krebs $^{2,3}$ (]
}

Received: 22 December 2020 / Accepted: 23 April 2021 / Published online: 3 May 2021

(c) The Author(s) 2021

\begin{abstract}
The presence of immune cells is a morphological hallmark of rapidly progressive glomerulonephritis, a disease group that includes anti-glomerular basement membrane glomerulonephritis, lupus nephritis, and anti-neutrophil cytoplasmic antibody (ANCA)-associated glomerulonephritis. The cellular infiltrates include cells from both the innate and the adaptive immune responses. The latter includes $\mathrm{CD} 4^{+}$and $\mathrm{CD}^{+} \mathrm{T}$ cells. In the past, $\mathrm{CD} 4^{+} \mathrm{T}$ cell subsets were viewed as terminally differentiated lineages with limited flexibility. However, it is now clear that Th17 cells can in fact have a high degree of plasticity and convert, for example, into pro-inflammatory Th1 cells or anti-inflammatory Tr1 cells. Interestingly, Th17 cells in experimental GN display limited spontaneous plasticity. Here we review the literature of $\mathrm{CD}^{+} \mathrm{T}$ cell plasticity focusing on immune-mediated kidney disease. We point out the key findings of the past decade, in particular that targeting pathogenic Th17 cells by anti-CD3 injection can be a tool to modulate the $\mathrm{CD} 4^{+} \mathrm{T}$ cell response. This anti-CD3 treatment can trigger a regulatory phenotype in Th17 cells and transdifferentiation of Th17 cells into immunosuppressive IL-10-expressing Tr1 cells (Tr1exTh17 cells). Thus, targeting Th17 cell plasticity could be envisaged as a new therapeutic approach in patients with glomerulonephritis.
\end{abstract}

Keywords Renal autoimmune disease $\cdot$ Th17 cells $\cdot$ T cell

\section{Introduction}

Glomerulonephritis (GN) is a heterogeneous group of diseases that cause immune-mediated injury of the renal glomerulus. The most aggressive form of glomerulonephritis, which can result in rapid decline in kidney function and shows glomerular necrosis, crescent formation, and immune cell invasion, including glomerular and periglomerular $\mathrm{T}$ cell infiltration is referred to as crescentic glomerulonephritis (cGN). The cause of cGN is a heterogeneous group of immune-mediated diseases that is classified into three types according to Couser (1988). Type $\mathrm{I}$ is driven by antibodies against the basal membrane as

Christian F. Krebs

c.krebs@uke.de

1 Hamburg Center for Translational Immunology (HCTI), University Medical Center Hamburg-Eppendorf, Hamburg, Germany

2 I. Department of Medicine, University Medical Center Hamburg-Eppendorf, Hamburg, Germany

3 Translational Immunology, III. Department of Medicine, University Medical Center Hamburg-Eppendorf, Hamburg, Germany observed in anti-glomerular basement membrane glomerulonephritis (anti-GBM GN) or the Goodpasture syndrome (antiGBM with pulmonary involvement). Type II is mediated by the accumulation of immune complexes, which is regularly seen in lupus nephritis (Tipping and Holdsworth 2006). Type III, the most common form of cGN, is histologically characterized by immune cell infiltration but absence of antibody depositions. Therefore, these entities have been termed pauciimmune glomerulonephritis. This form of $\mathrm{cGN}$ is associated with anti-neutrophil cytoplasmic autoantibodies (ANCA) (Couser 2012). All of these types of cGN cause intra-capillary and extra-capillary proliferation and infiltration with various types of immune cells (Janssen et al. 1998; Kurts et al. 2013).

The immune system is composed of different immune cells such as B cells, monocytes, and natural killer (NK) cells and of $\mathrm{CD} 8^{+}$and $\mathrm{CD} 4^{+} \mathrm{T}$ cells (Brodin and Davis 2017). Under physiological conditions, pro- and anti-inflammatory processes are balanced in order to maintain homeostasis (Foussat et al. 2003; Harrison et al. 2019). However, in autoimmune diseases, perturbations and imbalances in the immune cell composition and function can cause destructive inflammatory processes, which can result in glomerulonephritis (Lin and Zhang 2017) in the kidney. The concept 
of $\mathrm{T}$ cell involvement in the immunopathogenesis of glomerulonephritis is supported by MHC association studies in patients with ANCA-associated GN (Bonatti et al. 2014). In particular, $\mathrm{CD} 4^{+} \mathrm{T}$ cell responses are critically involved in immune-mediated tissue injury.

$\mathrm{CD}^{+} \mathrm{T}$ cells can be subdivided into different proinflammatory and anti-inflammatory subsets. Th1, Th2, and Th17 cells provide protection against exogenous offending agents but are also involved in cell-mediated autoimmunity. Regulatory T cells, such as Foxp $3^{+}$regulatory T cells (Treg cells) and type 1 regulatory T cells ( $\operatorname{Tr} 1$ cells), prevent autoimmune reactions and overwhelming effector responses. Importantly, the concept of stable lineage commitment of these $\mathrm{T}$ cell subsets has been challenged by publications that indicate alterations of the cytokine and transcriptional profile in T cells (Cano-Gamez et al. 2020; Gagliani et al. 2015; Hirota et al. 2011; Kiner et al. 2021). Th17 cells have been reported to be the main driver of immune-mediated diseases, and this $\mathrm{T}$ cell subset can have a high degree of plasticity, in that it can convert into other pro-inflammatory and antiinflammatory subsets. However, the mechanisms that drive plasticity versus stability and their relevance in autoimmunity are incompletely understood. Further insight will be key to develop novel therapeutic strategies targeting Th17 cell plasticity in autoimmunity (Krebs and Panzer 2018).

Autoimmune diseases can affect several organs, such as the central nervous system (CNS) in multiple sclerosis (MS), the intestine in inflammatory bowel disease (IBD), the joints in rheumatoid arthritis, and the kidneys in glomerulonephritis. However, what triggers the development of such autoimmune diseases is not yet completely understood. Genetic predisposition and spontaneous mutations have been described as influencing disease initiation and progression in affected patients. In addition, microbial and environmental factors have been reported to contribute to the pathological conditions (Begue et al. 2011; Engelhardt and Grimbacher 2014; Glocker et al. 2010; Xue and Mei 2019; Zhu et al. 2017).

The critical impact of Th1 and Th17 cells in the pathogenesis of glomerulonephritis has been demonstrated by our group and others (Krebs et al. 2013; Paust et al. 2009; Pisitkun et al. 2012; Summers et al. 2009). Interestingly, the shift from a Th17 dominated immune response at early stages of GN to a dominance of Th1 cells at a later time point raised the question of potential plasticity of Th17 cells and, specifically, whether they have the ability to convert into Th1 phenotypes (Paust et al. 2012).

The knowledge of $\mathrm{T}$ cell plasticity and stability mainly derives from animal models. However, the emergence of singlecell transcriptomics allows transcriptional states to be addressed in a comprehensive and unbiased fashion. From these investigations, developmental trajectories could be inferred that suggest transdifferentiation of T cells. Single-cell omics is covered in another article by Zhao et al. in this issue of the journal.
In this article, we will review the current literature on Th17 cell plasticity with a focus on immune-mediated kidney diseases. Moreover, we will discuss the role of pathogeninduced Th17 cells and potential therapeutic options.

\section{$\mathrm{CD4}^{+} \mathrm{T}$ cell subsets}

T cells play an important role in host defense and clearance of pathogens. T cells develop in the thymus and express unique $\mathrm{T}$ cell receptors (TCRs). While the majority of T cells express TCRs with $\alpha$ and $\beta$ chains (conventional T cells), others carry TCRs with a $y$ chain and a $\delta$ chain ( $\gamma \delta$ T cells).

Conventional $\mathrm{T}$ cells are separated into two groups which are defined by either $\mathrm{CD} 8$ or $\mathrm{CD} 4$ expression. $\mathrm{CD} 8^{+} \mathrm{T}$ cells, also referred to as cytotoxic $\mathrm{T}$ cells, respond to antigens presented by the MHC-I group, which are expressed on nucleated cells. These cells are mainly involved in cancer and virus elimination.

In contrast, $\mathrm{CD} 4^{+} \mathrm{T}$ cells are activated when they recognize antigens in the TCR, MHC-II, and peptide complex in their interaction with antigen-presenting cells (APCs) such as dendritic cells. This activation gives rise to cell differentiation into various $\mathrm{CD} 4^{+} \mathrm{T}$ cell subsets that orchestrate the immune response by secreting cytokines and other factors. These various $\mathrm{CD}^{+} \mathrm{T}$ cell subsets can exhibit both proinflammatory and anti-inflammatory functions.

The first description of different subsets of $\mathrm{CD} 4^{+} \mathrm{T}$ helper cells was published by Mosmann and Coffmann in 1986 (Mosmann et al. 1986). They have identified two types of $T$ helper cells (Th cells) that are distinguished by their cytokine and transcription factor profiles. These cells were referred to as Th1 and Th2. Th1 cells are characterized by the expression of the transcription factor T-bet and the production of the cytokines such as IL-12, the tumor necrosis factoralpha (TNF-a), and IFN-y (O'Shea and Paul 2010; Szabo et al. 2000). During Th1 cell differentiation, binding of IL-12 to its receptor plays a fundamental role (Kitching et al. 2005) by activating the signal transducer and activator of transcription-4 (STAT4). This can also result in the expression of IL-10 by Th1 cells (Neumann et al. 2014). T-bet, the master transcription factor of Th1 cells, is required for expression of IFN- $y$ in most of the T cell subsets (Thieu et al. 2008; Yang et al. 2020). Together, IFN- $y$ and T-bet drive the activation of STAT1 which is important for the maintenance of the Th1 phenotype by upregulating the IL-12R $\beta 2$ subunit (Afkarian et al. 2002; Kitching et al. 2005). The secretion of IFN- $y$ can even be enhanced by IL-12 expression together with IL-18 (Nakanishi et al. 2001). IFN-y-expressing T cells serve important functions in the host defense, in particular in the immune response against intracellular pathogens such as Mycobacterium tuberculosis or Mycobacterium lepromatosis (MartinezBarricarte et al. 2018; Yang et al. 2020). Th1 cells activate 
phagocytes, allowing infected cells to be eliminated and the anti-microbial response to be supported (Romagnani 1999). In addition, Th1 cells also have a protective capacity against viral infection by their migration to sites of inflammation and cytokine expression (Maloy et al. 2000).

The signature cytokines produced by Th2 cells are IL-4, IL-5, IL-9, and IL-13. Furthermore, Th2 cells are able to secrete IL-10 (Mosmann and Moore 1991). By upregulating IL-10, Th2 cells can inhibit Th1 cells by dampening IFN-y secretion (Mosmann and Moore 1991). IL-4 along with IL-2 is necessary for the differentiation of Th2 cells (Le Gros et al. 1990). To this end, the binding of IL-4 to its receptor results in an activation of the STAT6, which is important for the expression of the subset-specific transacting T cell-specific transcription factor GATA3 (Kaplan et al. 1996; Zheng and Flavell 1997).

Generally, Th2 cells play a fundamental role during infections with extracellular parasites like Nippostrongylus brasiliensis (Ozawa et al. 2005) or Schistosoma mansoni (Mosmann and Moore 1991). The release of IL-5 and IL-13 by Th2 cells can induce eosinophils which result in protection against parasites by pushing infected cells into apoptotic states (Martinez-Moczygemba and Huston 2003). In addition to these protective effects, Th2 cells are also involved in airway inflammation (Woodruff et al. 2009). Accordingly, many subtypes of asthma are associated with the abundance of Th2 cells in the lung.

Furthermore, other $\mathrm{CD}^{+} \mathrm{T}$ cell subsets have been identified in the past decade such as IL-9-expressing Th9 cells, IL-22-expressing Th22 cells, and follicular T helper cells (Tfh cells). However, the most prominent of those additional subsets might be Th17 cells, which are effector cells distinct from Th1 and Th2 cells (Harrington et al. 2005). Th17 cells express the transcription factor, ROR- $y t$, and secrete high levels of their signature cytokines IL-17A and IL-17F (Ivanov et al. 2006; Krummey et al. 2014). Usually, Th17 cells fight against pathogens; however, Th17 cells have been reported to drive autoimmune inflammation in the CNS, the skin, the intestine, and the kidneys (Esplugues et al. 2011; Krebs et al. 2016a; Langrish et al. 2005; Lowes et al. 2008; Park et al. 2005). In many conditions, Th17 cell proliferation and effector cytokine production can be controlled by Foxp $3^{+}$regulatory $\mathrm{T}$ cells and type 1 regulatory $\mathrm{T}$ cells $(\operatorname{Tr} 1)$, which do not express Foxp3 (Diefenhardt et al. 2018; Huber et al. 2011). These cells function as regulatory cells by suppressing effector cell proliferation and thereby restoring immune homeostasis. An important cytokine in this context is IL-10 that is mainly produced by regulatory $\mathrm{T}$ cells. The main focus of the next sections will be on the literature surrounding the $T$ cell subsets, Th17 cells, and regulatory T cells since they are of great importance during glomerulonephritis and are very promising as potential therapeutic targets.

\section{Th17 cell development and biology}

Th17 cells can be induced both in vitro and in vivo by stimulating TCR in the presence of specific cytokines (Ivanov et al. 2006). In mice and humans, IL-6 and transforming growth factor beta (TGF- $\beta$ ) are described as the drivers in Th17 cell development (Bettelli et al. 2006; Manel et al. 2008; Veldhoen et al. 2006). Although IL-23 does not seem to be a main driver of Th17 cell differentiation, it is reported to play an important role in their proliferation and maintenance (Bettelli et al. 2006; Veldhoen et al. 2006). Th17 cells are known to be induced by IL-6, IL-1 $\beta$, and IL-23 (Langrish et al. 2005; Lee et al. 2020), and this cytokine combination gives rise to more pathogenic Th17 cells. Some Th17 cells polarized in the presence of IL- $1 \beta$ and IL- 23 produce high levels of IL-22 (Chung et al. 2009). Recently, it was reported that IL-22-expressing Th17 cells produce high levels of IFN-y. These Th17 cells display a Th1-like phenotype and fulfill characteristics of pathogenic Th17 cells that strongly contribute to inflammation (Omenetti et al. 2019).

In contrast to these pathogenic Th17 cells, the combination of IL- 6 and TGF- $\beta$ is reported to induce, in part, nonpathogenic Th17 cells which can produce IL-10 (McGeachy et al. 2007). This IL-10 secretion under Th17 polarizing conditions is regulated by c-musculoaponeurotic fibrosarcoma (c-Maf), which in turn is induced by IL-6 and TGF- $\beta$ (Xu et al. 2009). Interestingly, RORyt, the master transcription factor of Th17 cells, also represses IL-10 production in Th17 cells and thereby sustains their effector function in intestinal inflammation (Sun et al. 2019).

In addition to cytokine production, differences between Th17 subsets can be observed at the transcriptional level (Lee et al. 2020). The gene signature of non-pathogenic or physiological Th17 cells is described as highly enriched for genes such as Maf, Ahr, and $I L-10$ (Lee et al. 2020). Pathogenic Th17 cells, on the other hand, express high levels of Csf2, Tbx21, and Gzmb (Lee et al. 2020).

IL-17A is described as a cytokine that is important for the fortification of the epithelial barrier in order to protect the host from pathogen invasion (Lee et al. 2015). Thereby, it has a crucial role in activating the innate immune system by recruiting neutrophils, for example (Disteldorf et al. 2015; Korn et al. 2009). Furthermore, Th17 cells that co-express IL-17A and IL-22 cells produce $\beta$-defensin, which is important for the secretion of anti-microbial peptides by epithelial cells (Liang et al. 2006). These anti-microbial peptides are important for host defense against bacterial infections. It is important to note that the Th17 immune response plays a critical role in maintaining the gut homeostasis. In this context, the reaction to antigens from invasive intestinal bacteria such as segmented filamentous bacteria (SFB), Escherichia coli $\mathrm{O} 157$, and Citrobacter rodentium induces intestinal Th17 cells (Atarashi et al. 2015; Ivanov et al. 2009; Sano 
et al. 2015). The bacterium Citrobacter rodentium is a welldescribed intestinal pathogen that causes tissue damage driven by proliferation of Th17 cells with inflammatory potential (Omenetti et al. 2019). Th17 cells display a protective role against Citrobacter rodentium infections. Although it is not the main cytokine that drives Th17 cell differentiation, IL-23 strongly drives Th17 function to fight against this pathogen (Mangan et al. 2006). Therefore, the natural presence of Th17 cells in the small intestine allows a fast Th17 cell response after infection. In addition to bacteria, fungi such as Candida albicans can induce Th17 cells (AcostaRodriguez et al. 2007; Sallusto 2016; Zielinski et al. 2012) and Th17 cell immune response and related cytokines have recently also been implicated in the immune response to SARS-CoV-2 (De Biasi et al. 2020; Zhao et al. 2021).

Although physiological Th17 cells are important for the maintenance of gut homeostasis and barrier integrity, the immune system can also give rise to pathogenic Th17 cells that contribute to pathological inflammation in intestinal and extra-intestinal diseases, including multiple sclerosis (Langrish et al. 2005), colitis (Lee et al. 2009), and glomerulonephritis (Kitching et al. 1999; Steinmetz et al. 2011).

Interestingly, renal Th17 cells in glomerulonephritis are related to Th17 cells in the intestine, as suggested by

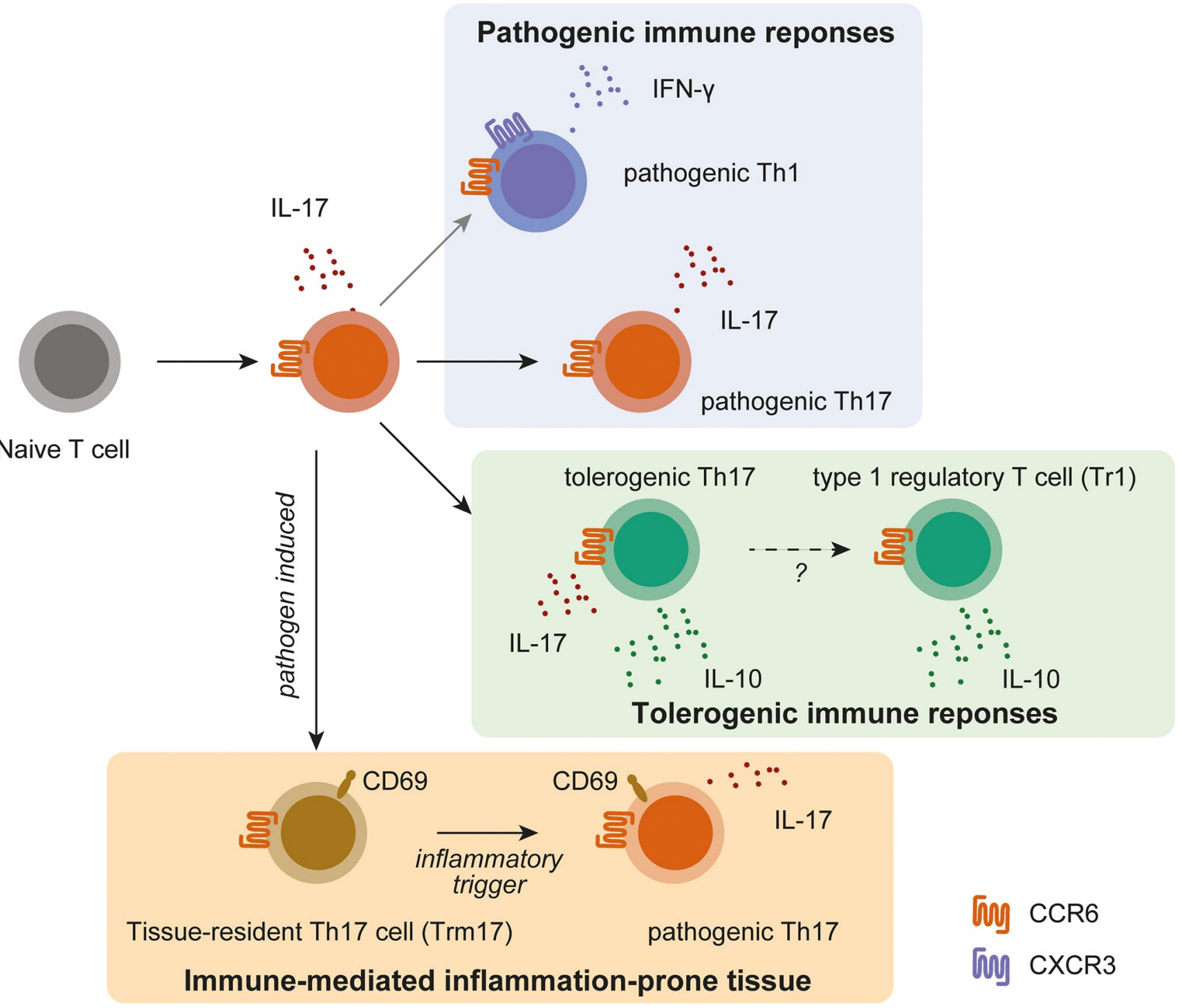

Fig. 1 Overview of potential differentiation routes of renal Th17 cells. IL-17-producing Th17 cells (red) can present a low degree of plasticity in experimental glomerulonephritis, and transdifferentiation into IFN-gamma-producing Th1 cells (blue) is less common in the kidney compared to findings in the inflamed central nervous system or in the intestine. Anti-CD3 treatment can induce IL-10-producing Th17 cells with a tolerogenic phenotype (green). Pathogen-induced Th17 cells develop into tissue-resident cells (Trm17) that can be activated by unspecific triggers and contribute to tissue damage in immune-mediated glomerulonephritis 
data coming from experimental glomerulonephritis (Krebs et al. 2016a) (Fig. 1). C-C motif chemokine receptor (CCR)-6 guides Th17 cells into the small intestine and the kidney (Esplugues et al. 2011; Krebs et al. 2016a). Interestingly, Th17 cells have the capacity to emigrate from the intestine in a S1PR1-dependent fashion and to migrate into the inflamed kidney, where they contribute to renal tissue damage in experimental GN (Krebs et al. 2016a).

\section{Th17 cell plasticity}

Originally, every $\mathrm{CD} 4^{+} \mathrm{T}$ cell subset was assumed to be stable after differentiation (Mosmann et al. 1986). This view of the $\mathrm{T}$ cell immune response has, however, been challenged in the last decade, and it is now accepted that $\mathrm{T}$ cells can display a high degree of plasticity. These $\mathrm{T}$ cells can actually change the expression of transcription factors and cytokines within one lifecycle (Gagliani et al. 2015; Wang et al. 2014). This change can be transient when cells coexpress cytokines. However, T cells can lose their transcriptional and cytokine signature and fully switch to another $\mathrm{T}$ cells subset, a process named transdifferentiation (Akamatsu et al. 2019). This phenotypical change can occur spontaneously, but it can also be influenced in vitro and in vivo. Therefore, $\mathrm{T}$ cell priming and the changes in the microenvironment can modulate $\mathrm{T}$ cell function and result in $\mathrm{T}$ cell plasticity (Nistala et al. 2010; Omenetti et al. 2019). The molecular network that drives $\mathrm{T}$ cell plasticity is still incompletely understood. However, a progressive adaptation to the tissue may play an important role (Miragaia et al. 2019). The concept of transdifferentiation is challenged by some authors as they postulate a phenotypic continuum of $\mathrm{T}$ cell subtypes (Kiner et al. 2021).

In the case of Th17 cells, transdifferentiation has been described as multidimensional in terms of cell fate. Th17 cell transdifferentiation can result in diverse functions. During EAE, some IFN- $\mathrm{y}$-producing cells are described as originating from Th17 cells (named exTh17 cells) (Gagliani et al. 2015; Hirota et al. 2011). $T$ cell transdifferentiation has been observed to promote the pathogenic properties of the cells within the host (Hirota et al. 2011; Komatsu et al. 2014). Likewise, Citrobacterinduced Th17 cells are highly plastic and mainly drive inflammation by expressing additional IFN- $y$ (Omenetti et al. 2019). In contrast, Th17 cells in the small intestine tend to upregulate IL-10 during transient gut inflammation induced by TCR-stimulation (Gagliani et al. 2015). Importantly, anti-inflammatory IL-10-producing Th17 cells can be converted in pro-inflammatory cells under the influence of IL-1ß (Noster et al. 2016; Zielinski et al. 2012). IL-10 upregulation is described as being driven by the transcription factor c-Maf that supports IL-27 driven IL-10 production in Th17 cells (Chang et al. 2017). A second antigen stimulation of human Th17 cells gives rise to anti-inflammatory Th17 cells expressing high levels of c-Maf, while pro-inflammatory Th17 cells do not upregulate c-Maf in this context (Aschenbrenner et al. 2018).

In addition to IL-10 and IL-17A co-expression, some Th17 cells have the ability to transdifferentiate into $\operatorname{Tr} 1$ cells. Those cells are termed $\operatorname{Tr} 1^{\text {exTh17 }}$ cells. Here, TGF- $\beta$ and Ahr are described as the main drivers of this conversion (Gagliani et al. 2015). $\operatorname{Tr} 1^{\text {exTh17}}$ cells mainly display a strong regulatory phenotype. Many factors favoring T cell plasticity have been described. Both $\mathrm{T}$ cell priming and the environment can drive $\mathrm{T}$ cell conversion (Omenetti et al. 2019). $\mathrm{T}$ cell conversion from effector cells expressing IL-10 has been described in the context of self-limitation (Neumann et al. 2014). Converted cells keep some characteristics of the effector cells from which they originated, such as mild expression of the CCR6 that guides pro-inflammatory and anti-inflammatory $\mathrm{T}$ cells to sites of inflammation. Furthermore, low levels of RORyt can be detected in exTh17 cells converted into $\operatorname{Tr} 1$ cells (Gagliani et al. 2015). Although these cells express chemokine receptors and transcription factors to a lesser extent than Th17 cells, the origin of the cell still potentially influences cell functions. During functional in vivo experiments, in comparison to conventional $\mathrm{Tr} 1$ cells that originate from naïve $\mathrm{CD} 4^{+} \mathrm{T}$ cells, both cells exhibit the same capacity to regulate colitis development (Gagliani et al. 2015).

The phenotype of effector Th17 cells with regard to their potential plasticity is dependent on the local microenvironment, defined by different tissues and inflammatory triggers (Krebs et al. 2016b). We are only beginning to understand what factors make up the micro-environmental factors that go beyond cytokines and cell-cell interactions, potentially including glucose levels, oxidative stress, fatty acids, and many more. Several publications from the past years have provided strong evidence that the local salt concentration critically impacts Th17 cells (Kleinewietfeld et al. 2013; Muller et al. 2019; Wu et al. 2013). Importantly, high salt concentrations can push either pro-inflammatory or anti-inflammatory Th17 cell (Luo et al. 2016; McGeachy et al. 2007) and the local cytokine milieu can control these two contradictory cell types (Matthias et al. 2020). Interestingly, renal Th17 cells in mice with experimental GN display a more stable phenotype as compared to Th17 cells in the inflamed CNS in experimental autoimmune encephalomyelitis (EAE) (Krebs et al. 2016b). When FACS-sorted, Th17 cells are investigated in experimental glomerulonephritis in transfer models, or IL-17A ${ }^{\mathrm{CRE}} \times$ Rosa $26^{\mathrm{YFP}}$ fate reporter mice are used to track Th17 cells over time, about $30 \%$ of these Th17 cells shut down their capacity to express IL-17A (Krebs et al. 2016b). Interestingly, additional TCRstimulation treatment with CD3-specific antibodies resulted in production of IL-10 in Th17 cells, and these treated mice showed less glomerular and tubulointerstitial kidney damage (Krebs et al. 2016b). 
As stated before, Th17 cells can be induced by different infectious triggers. However, until recently, it was known whether the infection-induced Th17 cells can also promote immune-mediated tissue injury. Interestingly, we identified that bloodstream infections by Staphylococcus aureus and Candida albicans and urinary tract infections by Escherichia coli can induce prominent Th17 immune responses, particularly in the kidney (Krebs et al. 2020). After these infections are cleared, Th17 cells become tissue resident and remain in the kidney over a long period of time. Interestingly, these tissue-resident Th17 cells (termed Trm17) can aggravate tissue injury in models of experimental glomerulonephritis. Of note, in terms of antigens, the antigens in experimental GN and the infectious triggers inducing these cells are very distinct. Single-cell RNA-sequencing revealed the major subsets that maintain the potential to express IL-17A and F of these Trm17 cells and revealed their profiled expression.

Based on these findings, different $\mathrm{T}$ cells subsets can potentially switch their phenotype from effector functions in infection to tissue-resident functions. These $\mathrm{T}$ cells can acquire innate-like functions and react to stimuli by cytokine expression in a TCR-independent manner. These T cells might be protective in infections but become pathogenic if immune-mediated tissue inflammation is established. Finally, these tissue-resident memory $\mathrm{T}$ cells in the kidney are a potential therapeutic target in patients with chronic remitting inflammation as seen in ANCA-associated vasculitis.

Collectively, these findings show that $\mathrm{T}$ cell differentiation is not a dead end in cellular development, but rather a temporary condition that can be influenced and pushed into regulatory programs by triggering the corresponding pathways.

\section{Generation and features of regulatory $T$ cells}

Regulatory $\mathrm{T}$ cells are necessary to control the immune response. There are two major subsets which show a strong capacity to suppress effector $\mathrm{T}$ cells: FoxP $3^{+}$regulatory $\mathrm{T}$ cells ( $\mathrm{T}$ reg cells) and type 1 regulatory $\mathrm{T}$ cells ( $\mathrm{Tr} 1$ cells). In both types of regulatory T cells, IL-10 plays a major role in cell maintenance and, thereby, in sustaining homeostasis (Brockmann et al. 2017). Foxp $3^{+}$Treg cells and Tr1 cells have the potential to suppress Th17 and Th1 cells directly via IL-10, which has been shown in the intestine (Huber et al. 2011).

Within the group of regulatory $\mathrm{T}$ cells, Treg cells are defined by the expression of its master transcription factor Foxp3 (Fontenot et al. 2005) and, indeed, Foxp3 expression is essential for the differentiation and maintenance of these immunosuppressive cells. On their surface, Foxp $3^{+}$ Treg cells express the IL-2 receptor a chain (Chinen et al. 2016). The activation of Foxp3 depends on IL-2 and
TGF- $\beta$ signaling (Chen et al. 2003; Zorn et al. 2006). These two cytokines are described in mice and humans and in the in vitro generation of Foxp $3^{+}$Treg cells. The important role of Foxp $3^{+}$Treg cells is shown when patients lack the gene, Foxp3, which results in the development of a fatal autoimmune disease (Bennett et al. 2001).

During inflammatory conditions, functional Foxp $3^{+}$ Treg cells exhibit a strong suppressive potential to inhibit Th17 and Th1 cells during colitis and glomerulonephritis, respectively (Huber et al. 2011; Kluger et al. 2014; Ostmann et al. 2013). Furthermore, in mice and humans, Foxp $3^{+}$ Treg cells were shown to significantly reduce kidney damage and to support acceptance of a transplant kidney by the host (Berglund et al. 2013; Savage et al. 2018). Endogenous IL-10 and IL-10 derived from Foxp $3^{+}$Treg cells is reported to ameliorate crescent formation, by modulating Th1 and Th17 cell responses (Kitching et al. 2000; Ostmann et al. 2013).

$\operatorname{Tr} 1$ cells are induced in the periphery and have been identified as potent suppressors of the immune system. They were originally defined based on the lack of Foxp3 expression and high expression of IL-10 (Roncarolo et al. 2014). Furthermore, $\operatorname{Tr} 1$ cells produce moderate levels of TGF- $\beta$ and IFN- $y$. However, the cytokines IL-4, IL-2, and IL-17A/F can also be expressed at very low levels by $\operatorname{Tr} 1$ cells (Gagliani et al. 2013). Originally, IL-10 was assumed to induce $\operatorname{Tr} 1$ cell generation. Until now, the role of IL-10 was shown during the regulation of stability and continuous IL-10 production by $\operatorname{Tr} 1$ cells (Brockmann et al. 2017). However, IL-27 has been identified to strongly induce the generation of $\operatorname{Tr} 1$ cells by the interaction of aryl hydrocarbon receptor (AHR) and c-Maf (Apetoh et al. 2010). Furthermore, in vitro, IL-27 and TGF- $\beta$ induce high numbers of $\operatorname{Tr} 1$ cells (Apetoh et al. 2010).

In contrast to other $\mathrm{T}$ cell subsets, there has not yet been a single transcription factor shown to be responsible for $\operatorname{Tr} 1$ cell differentiation. Nonetheless, various transcription factors are under discussion as to their involvement in $\operatorname{Tr} 1$ cell biology. These include Eomesodermin (Eomes) (Zhang et al. 2017), liver X receptor (LXR) (Brockmann et al. 2018), and early growth response 2 (Egr-2) (Okamura et al. 2009) in addition to c-Maf and PR domain zinc finger protein 1 (Blimp-1) (Chihara et al. 2018).

As described previously, $\operatorname{Tr} 1$ cells can originate from naïve $\mathrm{CD} 4^{+} \mathrm{T}$ cells. Interestingly, recent investigations show that they can also originate from former effector $\mathrm{T}$ cells (Gagliani et al. 2015). This generation was observed mainly in the small intestine when mice were injected with anti-CD3 antibody, which induces high numbers of suppressive $\operatorname{Tr} 1$ cells (Kamanaka et al. 2006). In this context, the generation of $\operatorname{Tr} 1$ cells from Th17 cells is dependent on TGF- $\beta$ and on the AHR (Gagliani et al. 2015). 
The administration of the anti-CD3 antibody leads to a strong induction of IL-17A in all parts of the small intestine (Esplugues et al. 2011). Furthermore, high numbers of regulatory cells are induced that have the ability to inhibit Th17 proliferation (Huber et al. 2011; Perruche et al. 2008). Tr1 cells play an important role in maintaining homeostasis during gut inflammation. First described in 1997, they have already been defined to be antigen-specific and successful in preventing colitis (Groux et al. 1997). The specific potency of $\operatorname{Tr} 1$ cells depends on their ability to produce and respond to IL-10 (Brockmann et al. 2017; Huber et al. 2011; Yao et al. 2015). IL-10 is a cytokine mostly associated with suppressive function. Regulation of pro-inflammatory cell types via IL-10 has been shown to be beneficial in healthy patients under homeostatic conditions. Also, in patients suffering from colitis or cGN, treatment with IL-10 or Tr1 cell-enriched $\mathrm{CD}^{+}{ }^{+} \mathrm{T}$ cell cocktail has strong potential to inhibit inflammatory responses (Desreumaux et al. 2012; Mfarrej et al. 2017; Petrelli et al. 2015; Soranno et al. 2016). Generally, in mice and humans that lack Tr1 cells, the development of spontaneous colitis can be observed (Engelhardt and Grimbacher 2014; Scheinin et al. 2003). Furthermore, when colitogenic mice are treated with IL-10, decreased levels of Th17 cells and IFN- $\gamma^{+}$Th17 cells can be observed (Huber et al. 2011).

Previously, it was shown that anti-CD3 antibody treatment ameliorates crescent formation and tubular damage during glomerulonephritis when administrated early after disease induction (Krebs et al. 2016b). Furthermore, antiCD3 antibody treatment increases IL-10 production in all analyzed $\mathrm{T}$ cell subsets. CD3-specific antibody treatment induces a rapid activation induced cell death which is also accompanied by a cytokine storm (Penaranda et al. 2011). Foxp $3^{+}$regulatory T cells and Th17 cells are also activated. However, these cells are more resistant to activation induced cell death (Penaranda et al. 2011; Shi et al. 2009; Yu et al. 2017). Furthermore, TGF- $\beta 1$ and IL-6, which are produced by phagocytes upon phagocytosis of the dead cells, further promote the expansion of the Foxp3 ${ }^{+}$Treg and Th17 cells (Bettelli et al. 2006; Chung et al. 2006; Fadok et al. 1998; Veldhoen et al. 2006; Zheng et al. 2007). Finally, Th17 cells, which are CCR6positive, are recruited via IL-17A induced CCL20 production by intestinal epithelial cells to the small intestine. Interestingly, Foxp $3^{+}$and Foxp $3^{-}$IL-10-producing $\mathrm{T}$ cells are likewise recruited to the small intestine and thereby limit intestinal inflammation and tissue damage (Huber et al. 2011; Kamanaka et al. 2006). Accordingly, in the small intestine, the treatment induces only transient inflammation (Clayburgh et al. 2005). In line with these data, increased frequencies of IL-10 producing $\mathrm{CD}^{+}{ }^{+} \mathrm{T}$ cells were observed. Of note, a protective effect of anti-CD3 antibody treatment was observed when mice were treated on days 6 and 8 after glomerulonephritis induction (Krebs et al. 2016b).

In line with the abovementioned data, previous publications have described SFB-induced Th17 cells as tissue resident and described them as not contributing to inflammation (Omenetti et al. 2019). In the gut, the Th17 cells actually exhibited a high level of plasticity; as a result of this, IFN-y-producing Th17 cells were present and these showed enhanced metabolic activity (Omenetti et al. 2019). Other studies have also described Th17 cells as showing high metabolic activity and as capable of converting to Th1 (Karmaus et al. 2019). It might be possible that in glomerulonephritis, a fraction of exTh17 cells actually convert to Th1 cells. Those cells might have additionally outranked the possible protective effect of the anti-CD3 antibody, and thus, protection could not be detected.

These findings indicate that similar $\mathrm{T}$ cells can display a different behavior and plasticity according to the microenvironment provided by different tissues.

\section{Concluding remarks}

Over the past decade, the way we view different $\mathrm{T}$ cell subsets has shifted substantially, largely on account of genetic models that allow the sorting of pure populations and the tracking of cell fates over time. Examples of these models are acute reporter mice and fate reporter mice. While initial observations suggested a terminally differentiated cell state within each subset, there can be substantial plasticity in the $\mathrm{T}$ cell compartment. Importantly, $\mathrm{T}$ cells have the ability to turn up and down effector functions and to differentiate into distinct effector types, but they can also acquire an immunosuppressive function.

The better understanding of the molecular mechanisms of $\mathrm{T}$ cell plasticity that has evolved over the past decade opens new avenues in treating immune-mediated diseases. By modulating $\mathrm{T}$ cell immune responses in a disease specific and a tissue-specific manner, detrimental $\mathrm{T}$ cell effector function could be converted into regulatory effects and therefore reduces immune-mediated inflammation. However, further studies are needed before these therapeutic concepts can be translated into clinical trials in the field of autoimmune kidney diseases.

Acknowledgements We thank Elaine Hussey for editing the paper.

Funding Open Access funding enabled and organized by Projekt DEAL. This work was supported by grants from the University Medical Center Hamburg-Eppendorf to S.S. and the Deutsche Forschungsgemeinschaft, DFG (SFB1192 Project A5) to S.H. and C.F.K. and grants from the Deutsche Nierenstiftung and Deutsche Gesellschaft für Nephrologie to C.F.K. 


\section{Declarations}

Ethical approval This article does not contain any studies with human participants or animals performed by any of the authors.

Conflict of interest The authors declare no competing interests.

Open Access This article is licensed under a Creative Commons Attribution 4.0 International License, which permits use, sharing, adaptation, distribution and reproduction in any medium or format, as long as you give appropriate credit to the original author(s) and the source, provide a link to the Creative Commons licence, and indicate if changes were made. The images or other third party material in this article are included in the article's Creative Commons licence, unless indicated otherwise in a credit line to the material. If material is not included in the article's Creative Commons licence and your intended use is not permitted by statutory regulation or exceeds the permitted use, you will need to obtain permission directly from the copyright holder. To view a copy of this licence, visit http://creativecommons.org/licenses/by/4.0/.

\section{References}

Acosta-Rodriguez EV, Rivino L, Geginat J, Jarrossay D, Gattorno M, Lanzavecchia A, Sallusto F, Napolitani G (2007) Surface phenotype and antigenic specificity of human interleukin 17-producing T helper memory cells. Nat Immunol 8:639-646

Afkarian M, Sedy JR, Yang J, Jacobson NG, Cereb N, Yang SY, Murphy TL, Murphy KM (2002) T-bet is a STAT1-induced regulator of IL$12 \mathrm{R}$ expression in naive CD4+ T cells. Nat Immunol 3:549-557

Akamatsu M, Mikami N, Ohkura N, Kawakami R, Kitagawa Y, Sugimoto A, Hirota K, Nakamura N, Ujihara S, Kurosaki T et al (2019) Conversion of antigen-specific effector/memory T cells into Foxp3-expressing Treg cells by inhibition of CDK8/19. Sci Immunol 4

Apetoh L, Quintana FJ, Pot C, Joller N, Xiao S, Kumar D, Burns EJ, Sherr DH, Weiner HL, Kuchroo VK (2010) The aryl hydrocarbon receptor interacts with c-Maf to promote the differentiation of type 1 regulatory $\mathrm{T}$ cells induced by IL-27. Nat Immunol 11:854-861

Aschenbrenner D, Foglierini M, Jarrossay D, Hu D, Weiner HL, Kuchroo VK, Lanzavecchia A, Notarbartolo S, Sallusto F (2018) An immunoregulatory and tissue-residency program modulated by c-MAF in human TH17 cells. Nat Immunol 19:1126-1136

Atarashi K, Tanoue T, Ando M, Kamada N, Nagano Y, Narushima S, Suda W, Imaoka A, Setoyama H, Nagamori T et al (2015) Th17 cell induction by adhesion of microbes to intestinal epithelial cells. Cell 163:367-380

Begue B, Verdier J, Rieux-Laucat F, Goulet O, Morali A, Canioni D, Hugot JP, Daussy C, Verkarre V, Pigneur B et al (2011) Defective IL10 signaling defining a subgroup of patients with inflammatory bowel disease. Am J Gastroenterol 106:1544-1555

Bennett CL, Christie J, Ramsdell F, Brunkow ME, Ferguson PJ, Whitesell L, Kelly TE, Saulsbury FT, Chance PF, Ochs HD (2001) The immune dysregulation, polyendocrinopathy, enteropathy, X-linked syndrome (IPEX) is caused by mutations of FOXP3. Nat Genet 27:20-21

Berglund D, Karlsson M, Biglarnia AR, Lorant T, Tufveson G, Korsgren O, Carlsson B (2013) Obtaining regulatory T cells from uraemic patients awaiting kidney transplantation for use in clinical trials. Clin Exp Immunol 173:310-322

Bettelli E, Carrier Y, Gao W, Korn T, Strom TB, Oukka M, Weiner HL, Kuchroo VK (2006) Reciprocal developmental pathways for the generation of pathogenic effector TH17 and regulatory T cells. Nature 441:235-238

Bonatti F, Reina M, Neri TM, Martorana D (2014) Genetic susceptibility to ANCA-associated vasculitis: state of the art. Front Immunol 5:577

Brockmann L, Gagliani N, Steglich B, Giannou AD, Kempski J, Pelczar P, Geffken M, Mfarrej B, Huber F, Herkel J et al (2017) IL-10 receptor signaling is essential for TR1 cell function in vivo. $\mathrm{J}$ Immunol 198:1130-1141

Brockmann L, Soukou S, Steglich B, Czarnewski P, Zhao L, Wende S, Bedke T, Ergen C, Manthey C, Agalioti T et al (2018) Molecular and functional heterogeneity of IL-10-producing CD4(+) T cells. Nat Commun 9:5457

Brodin P, Davis MM (2017) Human immune system variation. Nat Rev Immunol 17:21-29

Cano-Gamez E, Soskic B, Roumeliotis TI, So E, Smyth DJ, Baldrighi M, Wille D, Nakic N, Esparza-Gordillo J, Larminie CGC et al (2020) Single-cell transcriptomics identifies an effectorness gradient shaping the response of CD4(+) T cells to cytokines. Nat Commun 11:1801

Chang KK, Liu LB, Jin LP, Zhang B, Mei J, Li H, Wei CY, Zhou WJ, Zhu XY, Shao J et al (2017) IL-27 triggers IL-10 production in Th17 cells via a c-Maf/RORgammat/Blimp-1 signal to promote the progression of endometriosis. Cell Death Dis 8:e2666

Chen W, Jin W, Hardegen N, Lei KJ, Li L, Marinos N, McGrady G, Wahl SM (2003) Conversion of peripheral CD4+CD25- naive T cells to CD4+CD25+ regulatory T cells by TGF-beta induction of transcription factor Foxp3. J Exp Med 198:1875-1886

Chihara N, Madi A, Kondo T, Zhang H, Acharya N, Singer M, Nyman J, Marjanovic ND, Kowalczyk MS, Wang C et al (2018) Induction and transcriptional regulation of the co-inhibitory gene module in T cells. Nature 558:454-459

Chinen T, Kannan AK, Levine AG, Fan X, Klein U, Zheng Y, Gasteiger G, Feng Y, Fontenot JD, Rudensky AY (2016) An essential role for the IL-2 receptor in Treg cell function. Nat Immunol 17:1322-1333

Chung EY, Kim SJ, Ma XJ (2006) Regulation of cytokine production during phagocytosis of apoptotic cells. Cell Res 16:154-161

Chung Y, Chang SH, Martinez GJ, Yang XO, Nurieva R, Kang HS, Ma L, Watowich SS, Jetten AM, Tian Q, Dong C (2009) Critical regulation of early Th17 cell differentiation by interleukin-1 signaling. Immunity 30:576-587

Clayburgh DR, Barrett TA, Tang Y, Meddings JB, Van Eldik LJ, Watterson DM, Clarke LL, Mrsny RJ, Turner JR (2005) Epithelial myosin light chain kinase-dependent barrier dysfunction mediates $\mathrm{T}$ cell activation-induced diarrhea in vivo. J Clin Invest 115:2702-2715

Couser WG (1988) Rapidly progressive glomerulonephritis: classification, pathogenetic mechanisms, and therapy. Am J Kidney Dis $11: 449-464$

Couser WG (2012) Basic and translational concepts of immune-mediated glomerular diseases. J Am Soc Nephrol 23:381-399

De Biasi S, Meschiari M, Gibellini L, Bellinazzi C, Borella R, Fidanza L, Gozzi L, Iannone A, Lo Tartaro D, Mattioli M et al (2020) Marked $\mathrm{T}$ cell activation, senescence, exhaustion and skewing towards TH17 in patients with COVID-19 pneumonia. Nat Commun 11:3434

Desreumaux P, Foussat A, Allez M, Beaugerie L, Hebuterne X, Bouhnik Y, Nachury M, Brun V, Bastian H, Belmonte N et al (2012) Safety and efficacy of antigen-specific regulatory T-cell therapy for patients with refractory Crohn's disease. Gastroenterology 143(1207-1217):e1202

Diefenhardt P, Nosko A, Kluger MA, Richter JV, Wegscheid C, Kobayashi Y, Tiegs G, Huber S, Flavell RA, Stahl RAK, Steinmetz OM (2018) IL-10 receptor signaling empowers regulatory $\mathrm{T}$ cells to control Th17 responses and protect from GN. J Am Soc Nephrol 29:1825-1837

Disteldorf EM, Krebs CF, Paust HJ, Turner JE, Nouailles G, Tittel A, Meyer-Schwesinger C, Stege G, Brix S, Velden J et al (2015) 
CXCL5 drives neutrophil recruitment in TH17-mediated GN. J Am Soc Nephrol 26:55-66

Engelhardt KR, Grimbacher B (2014) IL-10 in humans: lessons from the gut, IL-10/IL-10 receptor deficiencies, and IL-10 polymorphisms. Curr Top Microbiol Immunol 380:1-18

Esplugues E, Huber S, Gagliani N, Hauser AE, Town T, Wan YY, O'Connor W Jr, Rongvaux A, Van Rooijen N, Haberman AM et al (2011) Control of TH17 cells occurs in the small intestine. Nature 475:514-518

Fadok VA, Bratton DL, Konowal A, Freed PW, Westcott JY, Henson PM (1998) Macrophages that have ingested apoptotic cells in vitro inhibit proinflammatory cytokine production through autocrine/ paracrine mechanisms involving TGF-beta, PGE2, and PAF. J Clin Invest 101:890-898

Fontenot JD, Rasmussen JP, Williams LM, Dooley JL, Farr AG, Rudensky AY (2005) Regulatory T cell lineage specification by the forkhead transcription factor foxp3. Immunity 22:329-341

Foussat A, Cottrez F, Brun V, Fournier N, Breittmayer JP, Groux H (2003) A comparative study between T regulatory type 1 and CD4+CD25+ T cells in the control of inflammation. J Immunol 171:5018-5026

Gagliani N, Amezcua Vesely MC, Iseppon A, Brockmann L, Xu H, Palm NW, de Zoete MR, Licona-Limon P, Paiva RS, Ching T et al (2015) Th17 cells transdifferentiate into regulatory T cells during resolution of inflammation. Nature 523:221-225

Gagliani N, Magnani CF, Huber S, Gianolini ME, Pala M, LiconaLimon P, Guo B, Herbert DR, Bulfone A, Trentini F et al (2013) Coexpression of CD49b and LAG-3 identifies human and mouse T regulatory type 1 cells. Nat Med 19:739-746

Glocker EO, Frede N, Perro M, Sebire N, Elawad M, Shah N, Grimbacher B (2010) Infant colitis-it's in the genes. Lancet 376:1272

Groux H, O'Garra A, Bigler M, Rouleau M, Antonenko S, de Vries JE, Roncarolo MG (1997) A CD4+ T-cell subset inhibits antigen-specific T-cell responses and prevents colitis. Nature 389:737-742

Harrington LE, Hatton RD, Mangan PR, Turner H, Murphy TL, Murphy KM, Weaver CT (2005) Interleukin 17-producing CD4+ effector $\mathrm{T}$ cells develop via a lineage distinct from the Thelper type 1 and 2 lineages. Nat Immunol 6:1123-1132

Harrison OJ, Linehan JL, Shih HY, Bouladoux N, Han SJ, Smelkinson M, Sen SK, Byrd AL, Enamorado M, Yao C et al (2019) Commensalspecific $\mathrm{T}$ cell plasticity promotes rapid tissue adaptation to injury. Science 363

Hirota K, Duarte JH, Veldhoen M, Hornsby E, Li Y, Cua DJ, Ahlfors H, Wilhelm C, Tolaini M, Menzel U et al (2011) Fate mapping of IL-17-producing T cells in inflammatory responses. Nat Immunol 12:255-263

Huber S, Gagliani N, Esplugues E, O'Connor W Jr, Huber FJ, Chaudhry A, Kamanaka M, Kobayashi Y, Booth CJ, Rudensky AY et al (2011) Th17 cells express interleukin-10 receptor and are controlled by Foxp3(-) and Foxp3+ regulatory CD4+ T cells in an interleukin-10-dependent manner. Immunity 34:554-565

Ivanov II, Atarashi K, Manel N, Brodie EL, Shima T, Karaoz U, Wei D, Goldfarb KC, Santee CA, Lynch SV et al (2009) Induction of intestinal Th17 cells by segmented filamentous bacteria. Cell 139:485-498

Ivanov II, McKenzie BS, Zhou L, Tadokoro CE, Lepelley A, Lafaille JJ, Cua DJ, Littman DR (2006) The orphan nuclear receptor RORgammat directs the differentiation program of proinflammatory IL-17+ T helper cells. Cell 126:1121-1133

Janssen U, Ostendorf T, Gaertner S, Eitner F, Hedrich HJ, Assmann KJ, Floege J (1998) Improved survival and amelioration of nephrotoxic nephritis in intercellular adhesion molecule-1 knockout mice. J Am Soc Nephrol 9:1805-1814

Kamanaka M, Kim ST, Wan YY, Sutterwala FS, Lara-Tejero M, Galan JE, Harhaj E, Flavell RA (2006) Expression of interleukin-10 in intestinal lymphocytes detected by an interleukin-10 reporter knockin tiger mouse. Immunity 25:941-952

Kaplan MH, Schindler U, Smiley ST, Grusby MJ (1996) Stat6 is required for mediating responses to IL-4 and for development of Th2 cells. Immunity 4:313-319

Karmaus PWF, Chen X, Lim SA, Herrada AA, Nguyen TM, Xu B, Dhungana Y, Rankin S, Chen W, Rosencrance C et al (2019) Metabolic heterogeneity underlies reciprocal fates of TH17 cell stemness and plasticity. Nature 565:101-105

Kiner E, Willie E, Vijaykumar B, Chowdhary K, Schmutz H, Chandler J, Schnell A, Thakore PI, LeGros G, Mostafavi S et al (2021) Gut CD4(+) T cell phenotypes are a continuum molded by microbes, not by TH archetypes. Nat Immunol 22:216-228

Kitching AR, Holdsworth SR, Tipping PG (1999) IFN-gamma mediates crescent formation and cell-mediated immune injury in murine glomerulonephritis. J Am Soc Nephrol 10:752-759

Kitching AR, Tipping PG, Timoshanko JR, Holdsworth SR (2000) Endogenous interleukin-10 regulates Th1 responses that induce crescentic glomerulonephritis. Kidney Int 57:518-525

Kitching AR, Turner AL, Wilson GR, Semple T, Odobasic D, Timoshanko JR, O'Sullivan KM, Tipping PG, Takeda K, Akira S, Holdsworth SR (2005) IL-12p40 and IL-18 in crescentic glomerulonephritis: IL-12p40 is the key Th1-defining cytokine chain, whereas IL-18 promotes local inflammation and leukocyte recruitment. J Am Soc Nephrol 16:2023-2033

Kleinewietfeld M, Manzel A, Titze J, Kvakan H, Yosef N, Linker RA, Muller DN, Hafler DA (2013) Sodium chloride drives autoimmune disease by the induction of pathogenic TH17 cells. Nature 496:518-522

Kluger MA, Luig M, Wegscheid C, Goerke B, Paust HJ, Brix SR, Yan I, Mittrucker HW, Hagl B, Renner ED et al (2014) Stat3 programs Th17-specific regulatory T cells to control GN. J Am Soc Nephrol 25:1291-1302

Komatsu N, Okamoto K, Sawa S, Nakashima T, Oh-hora M, Kodama T, Tanaka S, Bluestone JA, Takayanagi H (2014) Pathogenic conversion of Foxp3 + T cells into TH17 cells in autoimmune arthritis. Nat Med 20:62-68

Korn T, Bettelli E, Oukka M, Kuchroo VK (2009) IL-17 and Th17 cells. Annu Rev Immunol 27:485-517

Krebs CF, Kapffer S, Paust HJ, Schmidt T, Bennstein SB, Peters A, Stege G, Brix SR, Meyer-Schwesinger C, Muller RU et al (2013) MicroRNA-155 drives TH17 immune response and tissue injury in experimental crescentic GN. J Am Soc Nephrol 24:1955-1965

Krebs CF, Panzer U (2018) Plasticity and heterogeneity of Th17 in immune-mediated kidney diseases. J Autoimmun 87:61-68

Krebs CF, Paust HJ, Krohn S, Koyro T, Brix SR, Riedel JH, Bartsch P, Wiech T, Meyer-Schwesinger C, Huang J et al (2016a) Autoimmune renal disease is exacerbated by S1P-receptor-1-dependent intestinal Th17 cell migration to the kidney. Immunity 45:1078-1092

Krebs CF, Reimers D, Zhao Y, Paust HJ, Bartsch P, Nunez S, Rosemblatt MV, Hellmig M, Kilian C, Borchers A et al(2020) Pathogen-induced tissue-resident memory TH17 (TRM17) cells amplify autoimmune kidney disease. Sci Immunol 5

Krebs CF, Turner JE, Paust HJ, Kapffer S, Koyro T, Krohn S, Ufer F, Friese MA, Flavell RA, Stockinger B et al (2016b) Plasticity of Th17 cells in autoimmune kidney diseases. J Immunol 197:449-457

Krummey SM, Floyd TL, Liu D, Wagener ME, Song M, Ford ML (2014) Candida-elicited murine Th17 cells express high Ctla-4 compared with Th1 cells and are resistant to costimulation blockade. J Immunol 192:2495-2504

Kurts C, Panzer U, Anders HJ, Rees AJ (2013) The immune system and kidney disease: basic concepts and clinical implications. Nat Rev Immunol 13:738-753 
Langrish CL, Chen Y, Blumenschein WM, Mattson J, Basham B, Sedgwick JD, McClanahan T, Kastelein RA, Cua DJ (2005) IL-23 drives a pathogenic $\mathrm{T}$ cell population that induces autoimmune inflammation. J Exp Med 201:233-240

Le Gros G, Ben-Sasson SZ, Seder R, Finkelman FD, Paul WE (1990) Generation of interleukin 4 (IL-4)-producing cells in vivo and in vitro: IL-2 and IL-4 are required for in vitro generation of IL4-producing cells. J Exp Med 172:921-929

Lee JS, Tato CM, Joyce-Shaikh B, Gulen MF, Cayatte C, Chen Y, Blumenschein WM, Judo M, Ayanoglu G, McClanahan TK et al (2015) Interleukin-23-independent IL-17 production regulates intestinal epithelial permeability. Immunity 43:727-738

Lee JY, Hall JA, Kroehling L, Wu L, Najar T, Nguyen HH, Lin WY, Yeung ST, Silva HM, Li D et al (2020) Serum amyloid A proteins induce pathogenic Th17 cells and promote inflammatory disease. Cell 180(79-91):e16

Lee YK, Turner H, Maynard CL, Oliver JR, Chen D, Elson CO, Weaver CT (2009) Late developmental plasticity in the T helper 17 lineage. Immunity 30:92-107

Liang SC, Tan XY, Luxenberg DP, Karim R, Dunussi-Joannopoulos K, Collins M, Fouser LA (2006) Interleukin (IL)-22 and IL-17 are coexpressed by Th17 cells and cooperatively enhance expression of antimicrobial peptides. J Exp Med 203:2271-2279

Lin L, Zhang J (2017) Role of intestinal microbiota and metabolites on gut homeostasis and human diseases. BMC Immunol 18:2

Lowes MA, Kikuchi T, Fuentes-Duculan J, Cardinale I, Zaba LC, Haider AS, Bowman EP, Krueger JG (2008) Psoriasis vulgaris lesions contain discrete populations of Th1 and Th17 T cells. J Invest Dermatol 128:1207-1211

Luo T, Ji WJ, Yuan F, Guo ZZ, Li YX, Dong Y, Ma YQ, Zhou X, Li YM (2016) Th17/Treg imbalance induced by dietary salt variation indicates inflammation of target organs in humans. Sci Rep 6:26767

Maloy KJ, Burkhart C, Junt TM, Odermatt B, Oxenius A, Piali L, Zinkernagel RM, Hengartner H (2000) CD4(+) T cell subsets during virus infection. Protective capacity depends on effector cytokine secretion and on migratory capability. J Exp Med 191:2159-2170

Manel N, Unutmaz D, Littman DR (2008) The differentiation of human $\mathrm{T}(\mathrm{H})-17$ cells requires transforming growth factor-beta and induction of the nuclear receptor RORgammat. Nat Immunol 9:641-649

Mangan PR, Harrington LE, O'Quinn DB, Helms WS, Bullard DC, Elson CO, Hatton RD, Wahl SM, Schoeb TR, Weaver CT (2006) Transforming growth factor-beta induces development of the $\mathrm{T}(\mathrm{H}) 17$ lineage. Nature 441:231-234

Martinez-Barricarte R, Markle JG, Ma CS, Deenick EK, RamirezAlejo N, Mele F, Latorre D, Mahdaviani SA, Aytekin C, Mansouri D et al (2018) Human IFN-gamma immunity to mycobacteria is governed by both IL-12 and IL-23. Sci Immunol 3

Martinez-Moczygemba M, Huston DP (2003) Biology of common beta receptor-signaling cytokines: IL-3, IL-5, and GM-CSF. J Allergy Clin Immunol 112:653-665; quiz 666

Matthias J, Heink S, Picard F, Zeitrag J, Kolz A, Chao YY, Soll D, de Almeida GP, Glasmacher E, Jacobsen ID et al (2020) Salt generates antiinflammatory Th17 cells but amplifies pathogenicity in proinflammatory cytokine microenvironments. J Clin Invest 130:4587-4600

McGeachy MJ, Bak-Jensen KS, Chen Y, Tato CM, Blumenschein W, McClanahan T, Cua DJ (2007) TGF-beta and IL-6 drive the production of IL-17 and IL-10 by T cells and restrain T(H)-17 cellmediated pathology. Nat Immunol 8:1390-1397

Mfarrej B, Tresoldi E, Stabilini A, Paganelli A, Caldara R, Secchi A, Battaglia M (2017) Generation of donor-specific Tr1 cells to be used after kidney transplantation and definition of the timing of their in vivo infusion in the presence of immunosuppression. J Transl Med 15:40

Miragaia RJ, Gomes T, Chomka A, Jardine L, Riedel A, Hegazy AN, Whibley N, Tucci A, Chen X, Lindeman I et al (2019) Single-cell transcriptomics of regulatory $\mathrm{T}$ cells reveals trajectories of tissue adaptation. Immunity 50(493-504):e497

Mosmann TR, Cherwinski H, Bond MW, Giedlin MA, Coffman RL (1986) Two types of murine helper T cell clone. I. Definition according to profiles of lymphokine activities and secreted proteins. J Immunol 136:2348-2357

Mosmann TR, Moore KW (1991) The role of IL-10 in crossregulation of $\mathrm{TH} 1$ and $\mathrm{TH} 2$ responses. Immunol Today 12:A49-53

Muller DN, Wilck N, Haase S, Kleinewietfeld M, Linker RA (2019) Sodium in the microenvironment regulates immune responses and tissue homeostasis. Nat Rev Immunol 19:243-254

Nakanishi K, Yoshimoto T, Tsutsui H, Okamura H (2001) Interleukin-18 regulates both Th1 and Th2 responses. Annu Rev Immunol 19:423-474

Neumann C, Heinrich F, Neumann K, Junghans V, Mashreghi MF, Ahlers J, Janke M, Rudolph C, Mockel-Tenbrinck N, Kuhl AA et al (2014) Role of Blimp-1 in programing Th effector cells into IL-10 producers. J Exp Med 211:1807-1819

Nistala K, Adams S, Cambrook H, Ursu S, Olivito B, de Jager W, Evans JG, Cimaz R, Bajaj-Elliott M, Wedderburn LR (2010) Th17 plasticity in human autoimmune arthritis is driven by the inflammatory environment. Proc Natl Acad Sci U S A 107:14751-14756

Noster R, de Koning HD, Maier E, Prelog M, Lainka E, Zielinski CE (2016) Dysregulation of proinflammatory versus antiinflammatory human TH17 cell functionalities in the autoinflammatory Schnitzler syndrome. J Allergy Clin Immunol 138(1161-1169):e1166

O'Shea JJ, Paul WE (2010) Mechanisms underlying lineage commitment and plasticity of helper CD4+ T cells. Science 327:1098-1102

Okamura T, Fujio K, Shibuya M, Sumitomo S, Shoda H, Sakaguchi S, Yamamoto K (2009) CD4+CD25-LAG3+ regulatory T cells controlled by the transcription factor Egr-2. Proc Natl Acad Sci U S A 106:13974-13979

Omenetti S, Bussi C, Metidji A, Iseppon A, Lee S, Tolaini M, Li Y, Kelly G, Chakravarty P, Shoaie S et al (2019) The intestine harbors functionally distinct homeostatic tissue-resident and inflammatory Th17 cells. Immunity 51(77-89):e76

Ostmann A, Paust HJ, Panzer U, Wegscheid C, Kapffer S, Huber S, Flavell RA, Erhardt A, Tiegs G (2013) Regulatory T cell-derived IL-10 ameliorates crescentic GN. J Am Soc Nephrol 24:930-942

Ozawa H, Tamauchi H, Ito M, Terashima M, Inoue M, Hozumi K, Habu S, Watanabe N (2005) Immune responses to Nippostrongylus brasiliensis and tuberculin protein in GATA-3-transgenic mice. Immunol Lett 99:228-235

Park H, Li Z, Yang XO, Chang SH, Nurieva R, Wang YH, Wang Y, Hood L, Zhu Z, Tian Q, Dong C (2005) A distinct lineage of $\mathrm{CD} 4 \mathrm{~T}$ cells regulates tissue inflammation by producing interleukin 17. Nat Immunol 6:1133-1141

Paust HJ, Turner JE, Riedel JH, Disteldorf E, Peters A, Schmidt T, Krebs C, Velden J, Mittrucker HW, Steinmetz OM et al (2012) Chemokines play a critical role in the cross-regulation of Th1 and Th17 immune responses in murine crescentic glomerulonephritis. Kidney Int 82:72-83

Paust HJ, Turner JE, Steinmetz OM, Peters A, Heymann F, Holscher C, Wolf G, Kurts C, Mittrucker HW, Stahl RA, Panzer U (2009) The IL-23/Th17 axis contributes to renal injury in experimental glomerulonephritis. J Am Soc Nephrol 20:969-979

Penaranda C, Tang Q, Bluestone JA (2011) Anti-CD3 therapy promotes tolerance by selectively depleting pathogenic cells while preserving regulatory T cells. J Immunol 187:2015-2022

Perruche S, Zhang P, Liu Y, Saas P, Bluestone JA, Chen W (2008) CD3-specific antibody-induced immune tolerance involves 
transforming growth factor-beta from phagocytes digesting apoptotic T cells. Nat Med 14:528-535

Petrelli A, Tresoldi E, Mfarrej BG, Paganelli A, Spotti D, Caldara R, Secchi A, Battaglia M (2015) Generation of donor-specific T regulatory type 1 cells from patients on dialysis for cell therapy after kidney transplantation. Transplantation 99:1582-1589

Pisitkun P, Ha HL, Wang H, Claudio E, Tivy CC, Zhou H, Mayadas TN, Illei GG, Siebenlist U (2012) Interleukin-17 cytokines are critical in development of fatal lupus glomerulonephritis. Immunity $37: 1104-1115$

Romagnani S (1999) Th1/Th2 cells. Inflamm Bowel Dis 5:285-294

Roncarolo MG, Gregori S, Bacchetta R, Battaglia M (2014) Tr1 cells and the counter-regulation of immunity: natural mechanisms and therapeutic applications. Curr Top Microbiol Immunol 380:39-68

Sallusto F (2016) Heterogeneity of human CD4(+) T cells against microbes. Annu Rev Immunol 34:317-334

Sano T, Huang W, Hall JA, Yang Y, Chen A, Gavzy SJ, Lee JY, Ziel JW, Miraldi ER, Domingos AI et al (2015) An IL-23R/IL-22 circuit regulates epithelial serum amyloid A to promote local effector Th17 responses. Cell 163:381-393

Savage TM, Shonts BA, Obradovic A, Dewolf S, Lau S, Zuber J, Simpson MT, Berglund, E, Fu J, Yang S et al (2018) Early expansion of donorspecific Tregs in tolerant kidney transplant recipients. JCI Insight 3

Scheinin T, Butler DM, Salway F, Scallon B, Feldmann M (2003) Validation of the interleukin-10 knockout mouse model of colitis: antitumour necrosis factor-antibodies suppress the progression of colitis. Clin Exp Immunol 133:38-43

Shi G, Ramaswamy M, Vistica BP, Cox CA, Tan C, Wawrousek EF, Siegel RM, Gery I (2009) Unlike Th1, Th17 cells mediate sustained autoimmune inflammation and are highly resistant to restimulation-induced cell death. J Immunol 183:7547-7556

Soranno DE, Rodell CB, Altmann C, Duplantis J, Andres-Hernando A, Burdick JA, Faubel S (2016) Delivery of interleukin-10 via injectable hydrogels improves renal outcomes and reduces systemic inflammation following ischemic acute kidney injury in mice. Am J Physiol Renal Physiol 311:F362-372

Steinmetz OM, Summers SA, Gan PY, Semple T, Holdsworth SR, Kitching AR (2011) The Th17-defining transcription factor RORgammat promotes glomerulonephritis. J Am Soc Nephrol 22:472-483

Summers SA, Steinmetz OM, Li M, Kausman JY, Semple T, Edgtton KL, Borza DB, Braley H, Holdsworth SR, Kitching AR (2009) Th1 and Th17 cells induce proliferative glomerulonephritis. J Am Soc Nephrol 20:2518-2524

Sun M, He C, Chen L, Yang W, Wu W, Chen F, Cao AT, Yao S, Dann SM, Dhar TGM et al (2019) RORgammat represses IL-10 production in Th17 cells to maintain their pathogenicity in inducing intestinal inflammation. J Immunol 202:79-92

Szabo SJ, Kim ST, Costa GL, Zhang X, Fathman CG, Glimcher LH (2000) A novel transcription factor, T-bet, directs Th1 lineage commitment. Cell 100:655-669

Thieu VT, Yu Q, Chang HC, Yeh N, Nguyen ET, Sehra S, Kaplan MH (2008) Signal transducer and activator of transcription 4 is required for the transcription factor T-bet to promote $\mathrm{T}$ helper 1 cell-fate determination. Immunity 29:679-690

Tipping PG, Holdsworth SR (2006) T cells in crescentic glomerulonephritis. J Am Soc Nephrol 17:1253-1263

Veldhoen M, Hocking RJ, Atkins CJ, Locksley RM, Stockinger B (2006) TGFbeta in the context of an inflammatory cytokine milieu supports de novo differentiation of IL-17-producing T cells. Immunity 24:179-189
Wang Y, Godec J, Ben-Aissa K, Cui K, Zhao K, Pucsek AB, Lee YK, Weaver CT, Yagi R, Lazarevic V (2014) The transcription factors T-bet and Runx are required for the ontogeny of pathogenic interferon-gamma-producing T helper 17 cells. Immunity 40:355-366

Woodruff PG, Modrek B, Choy DF, Jia G, Abbas AR, Ellwanger A, Koth LL, Arron JR, Fahy JV (2009) T-helper type 2-driven inflammation defines major subphenotypes of asthma. Am J Respir Crit Care Med 180:388-395

Wu C, Yosef N, Thalhamer T, Zhu C, Xiao S, Kishi Y, Regev A, Kuchroo VK (2013) Induction of pathogenic TH17 cells by inducible salt-sensing kinase SGK1. Nature 496:513-517

Xu J, Yang Y, Qiu G, Lal G, Wu Z, Levy DE, Ochando JC, Bromberg JS, Ding Y (2009) c-Maf regulates IL-10 expression during Th17 polarization. J Immunol 182:6226-6236

Xue C, Mei CL (2019) Polycystic kidney disease and renal fibrosis. Adv Exp Med Biol 1165:81-100

Yang R, Mele F, Worley L, Langlais D, Rosain J, Benhsaien I, Elarabi H, Croft CA, Doisne JM, Zhang P et al (2020) Human T-bet governs innate and innate-like adaptive IFN-gamma immunity against mycobacteria. Cell 183(1826-1847):e1831

Yao Y, Vent-Schmidt J, McGeough MD, Wong M, Hoffman HM, Steiner TS, Levings MK (2015) Tr1 cells, but not Foxp3+ regulatory $\mathrm{T}$ cells, suppress NLRP3 inflammasome activation via an IL-10-dependent mechanism. J Immunol 195:488-497

Yu H, Gagliani N, Ishigame H, Huber S, Zhu S, Esplugues E, Herold KC, Wen L, Flavell RA (2017) Intestinal type 1 regulatory T cells migrate to periphery to suppress diabetogenic $\mathrm{T}$ cells and prevent diabetes development. Proc Natl Acad Sci U S A 114:10443-10448

Zhang P, Lee JS, Gartlan KH, Schuster IS, Comerford I, Varelias A, Ullah MA, Vuckovic S, Koyama M, Kuns RD et al (2017) Eomesodermin promotes the development of type 1 regulatory T (TR1) cells. Sci Immunol 2

Zhao Y, Kilian C, Turner JE, Bosurgi L, Roedl K, Bartsch P, Gnirck AC, Cortesi F, Schultheiss C, Hellmig M et al (2021) Clonal expansion and activation of tissue-resident memory-like Th17 cells expressing GM-CSF in the lungs of severe COVID-19 patients. Sci Immunol 6:eabf6692

Zheng SG, Wang J, Wang P, Gray JD, Horwitz DA (2007) IL-2 is essential for TGF-beta to convert naive CD4+CD25- cells to CD25+Foxp3+ regulatory $\mathrm{T}$ cells and for expansion of these cells. J Immunol 178:2018-2027

Zheng W, Flavell RA (1997) The transcription factor GATA-3 is necessary and sufficient for Th2 cytokine gene expression in CD4 T cells. Cell 89:587-596

Zhu L, Shi T, Zhong C, Wang Y, Chang M, Liu X (2017) IL-10 and IL-10 receptor mutations in very early onset inflammatory bowel disease. Gastroenterology Res 10:65-69

Zielinski CE, Mele F, Aschenbrenner D, Jarrossay D, Ronchi F, Gattorno M, Monticelli S, Lanzavecchia A, Sallusto F (2012) Pathogeninduced human TH17 cells produce IFN-gamma or IL-10 and are regulated by IL-1beta. Nature 484:514-518

Zorn E, Nelson EA, Mohseni M, Porcheray F, Kim H, Litsa D, Bellucci R, Raderschall E, Canning C, Soiffer RJ et al (2006) IL-2 regulates FOXP3 expression in human CD4+CD25+ regulatory T cells through a STAT-dependent mechanism and induces the expansion of these cells in vivo. Blood 108:1571-1579

Publisher's Note Springer Nature remains neutral with regard to jurisdictional claims in published maps and institutional affiliations. 